\title{
Effectiveness Assessment of Using Riverine Water eDNA to Simultaneously Monitor the Riverine and Riparian Biodiversity Information
}

\section{Haile Yang}

Yangtze River Fisheries Research Institute, Chinese Academy of Fishery Sciences

Hao Du ( $\nabla$ duhao@yfi.ac.cn )

Yangtze River Fisheries Research Institute, Chinese Academy of Fishery Sciences

Hongfang Qi

Rescue and Rehabilitation Center of Naked Carps of Qinghai Lake

\section{Luxian Yu}

Rescue and Rehabilitation Center of Naked Carps of Qinghai Lake

\section{Xindong Hou}

China University of Geoscience

\section{Hui Zhang}

Yangtze River Fisheries Research Institute, Chinese Academy of Fishery Sciences

Junyi Li

Yangtze River Fisheries Research Institute, Chinese Academy of Fishery Sciences

\section{Jinming Wu}

Yangtze River Fisheries Research Institute, Chinese Academy of Fishery Sciences

\section{Chengyou Wang}

Yangtze River Fisheries Research Institute, Chinese Academy of Fishery Sciences

\section{Qiong Zhou}

Yangtze River Fisheries Research Institute, Chinese Academy of Fishery Sciences

\section{Qiwei Wei}

Yangtze River Fisheries Research Institute, Chinese Academy of Fishery Sciences

\section{Research Article}

Keywords: aquatic and terrestrial biodiversity, eDNA, Qinghai-Tibet Plateau, eukaryotic biodiversity

Posted Date: September 17th, 2021

DOl: https://doi.org/10.21203/rs.3.rs-880062/v1

License: (9) (1) This work is licensed under a Creative Commons Attribution 4.0 International License. Read Full License

Version of Record: A version of this preprint was published at Scientific Reports on December 1st, 2021. See the published version at https://doi.org/10.1038/s41598-021-03733-7. 


\section{Abstract}

Both aquatic and terrestrial biodiversity information can be detected in riverine water environmental DNA (eDNA). However, the effectiveness of using riverine water eDNA to simultaneously monitor the riverine and terrestrial biodiversity information remains unidentified. Here, we proposed that the monitoring effectiveness could be approximated by the transportation effectiveness of land-to-river and upstream-to-downstream biodiversity information flows and described by three new indicators. Subsequently, we conducted a case study in a watershed on the Qinghai-Tibet Plateau. The results demonstrated that there was higher monitoring effectiveness on summer or autumn rainy days than in other seasons and weather conditions. The monitoring of the bacterial biodiversity information was more efficient than the monitoring of the eukaryotic biodiversity information. On summer rainy days, $43-76 \%$ of species information in riparian sites could be detected in water eDNA samples, $92-99 \%$ of species information in riverine sites could be detected in a 1-km downstream eDNA sample, and half of dead bioinformation (i.e., the bioinformation labeling the biological material that lacked life activity and fertility) could be monitored 4-6 km downstream for eukaryotes and 13-19 km downstream for bacteria. The current study provided reference method and data for future monitoring projects design and for future monitoring results evaluation.

\section{Introduction}

Biodiversity monitoring is the basis of ecological research, biodiversity conservation and ecosystem management ${ }^{1,2}$. Traditional biodiversity monitoring methods are cost- and time-consuming and require high levels of expertise, in which biodiversity is often studied from a local and low spatio-temporal resolution perspective and is generally not available at a wide taxonomic breadth, high spatio-temporal resolution and large spatio-temporal scale ${ }^{3-5}$. This limits the development of ecological research, biodiversity conservation and ecosystem management. Currently, metabarcoding and high-throughput sequencing of environmental DNA (eDNA, DNA extracted from environmental samples such as water, soil, and air) provide novel opportunities to monitor biodiversity ${ }^{5-9}$. As an efficient and easy-to-standardize non-invasive monitoring approach ${ }^{6,10-12}$, and with the continuous advancements in DNA sequencing technology, using eDNA metabarcoding to monitor biodiversity is an appropriate method to revolutionize biodiversity monitoring by enabling the census of wide taxonomic species on a high spatio-temporal resolution and large spatio-temporal scale $\mathrm{e}^{4,6,13,14}$. Streams and rivers connect upstream and downstream regions, connect land with waterbodies, and transport materials and information through extensive and heterogeneous network systems ${ }^{6,15,16}$. Riverine water eDNA incorporates biodiversity information across terrestrial and aquatic biomes ${ }^{6,16}$. Therefore, a sample of riverine water eDNA has the potential to simultaneously monitor both aquatic and terrestrial biodiversity information of a watershed for biodiversity research, conservation, and management. However, its viability and monitoring effectiveness (represented by the proportion of aquatic and terrestrial biodiversity information that can be detected by using limited riverine water eDNA samples) has not been systematically identified.

The effectiveness of using riverine water eDNA to simultaneously monitor both aquatic and terrestrial biodiversity depends on the land-to-river and upstream-to-downstream transportation effectiveness of the terrestrial and upstream biodiversity information 6,17-20. The biodiversity information monitoring effectiveness could be approximated by assessing the land-to-river and upstream-to-downstream transportation effectiveness of the corresponding bioinformation (eDNA). Here we defined the land-to-river and upstream-to-downstream bioinformation transportation, which is driven by watershed ecosystem processes, as the watershed biological information flow (WBIF). WBIF integrates the ecological processes of eDNA, including the origin, state, transport, and fate of eDNA ${ }^{14,15,21-23}$. The transportation effectiveness of WBIF mainly relies on the transport capacity, degradation rate, and environmental filtration of WBIF ${ }^{15,21-23}$. The transport capacity of WBIF mainly depends on erosion and runoff ${ }^{12,15,24}$. Additionally, the degradation rate of WBIF mainly depends on environmental features ${ }^{21,25,26}$, and the environmental filtration of WBIF mainly depends on the environmental changes of restricting organisms. Collectively, all of these factors are related to the seasons and weather conditions ${ }^{26}$. Therefore, we hypothesized that the monitoring effectiveness of riverine water eDNA would vary with the seasons and weather conditions. Moreover, due to taxonomy-specific eDNA degradation rates ${ }^{27}$, species-specific eDNA degradation rates ${ }^{17}$, and form-specific eDNA degradation rates ${ }^{28}$, we hypothesized that the monitoring effectiveness of riverine water eDNA would vary with taxonomic communities. 
Herein, we proposed that, in order to identify the effectiveness of using riverine water eDNA to simultaneously monitor the riverine and terrestrial biodiversity information, we needed to assess the transportation effectiveness of land-to-river and upstream-to-downstream WBIF for different taxonomic communities in different seasons and weather conditions. In the present study, we conducted a case study in a watershed on the Qinghai-Tibet Plateau to test the eDNA monitoring effectiveness assessment framework. We estimated the monitoring effectiveness, as indicated by the biodiversity information of three taxonomic communities in three seasons and weather conditions. Our objectives were threefold: (1) to identify the variation in biodiversity information monitoring effectiveness in different seasons and weather conditions; (2) to identify the variation in the effectiveness for monitoring the biodiversity information of different taxonomic communities; and (3) to test the monitoring effectiveness assessment framework. The current work identified the effectiveness of using riverine water eDNA to simultaneously monitor the biodiversity information in riverine sites and riparian sites on the Qinghai-Tibet Plateau and tested the assessment framework.

\section{Results}

\section{WBIF of the Three Seasonal Groups}

A total of 10,602, 13,766, and 16,500 bacterial OTU types were detected from the samples (including 9 water samples and 9 soil samples, Fig. 1) of the spring, summer, and autumn group, respectively (Fig. 2 and Table S1). The total types of OTUs that were detected from the soil eDNA samples were similar among the seasons (Figs. 2,3). The total types of OTUs that were detected from the water eDNA samples were richest in the autumn (Figs. 2,3). The common types of OTUs that were shared between the soil eDNA and water eDNA samples accounted for $36.30 \%, 71.98 \%$, and $67.58 \%$ of the total OTU types that were detected in the soil eDNA samples in the spring, summer, and autumn groups, respectively (Fig. 3).

The transportation effectiveness values of WBIF, as indicated by bacterial OTUs from the riparian sampling site to the adjacent riverine sampling site, were $16.62 \%, 62.76 \%$, and $48.09 \%$ on spring frozen, summer rainy, and autumn cloudy days, respectively, among which there was the highest transport capacity and the lowest environmental filtration on the summer rainy day (Tables 1,S2). The transportation effectiveness of WBIF indicated by bacterial OTUs from upstream to downstream was $75.86 \%$, $97.41 \%$, and $96.07 \%$ per km on spring frozen, summer rainy, and autumn cloudy days, respectively (Tables 2,S3), among which the transport capacity was more than $99 \%$ in all three seasons and the least noneffective WBIF (dead bioinformation) occurred; the longest half-life distance of the noneffective WBIF occurred on the summer rainy day (Table 2).

Table 1

Seasonal variation of transport capacity, environmental filtration, and transportation effectiveness of watershed biological information flow (WBIF) from the riparian sampling site to adjacent riverine water sampling site in three seasons indicated by bacterial OTUs

\begin{tabular}{|lllll|}
\hline Seasonal group & Weather condition & Transport capacity & Environmental filtration & Transportation effectiveness \\
\hline Spring group & Frozen days & $0.268791 \pm 0.202388$ & $0.385443 \pm 0.029320$ & $0.166152 \pm 0.125394$ \\
\hline Summer group & Rainy days & $0.684876 \pm 0.091302$ & $0.083816 \pm 0.020574$ & $0.627643 \pm 0.087327$ \\
\hline Autumn group & Cloudy days & $0.573579 \pm 0.052897$ & $0.161800 \pm 0.045075$ & $0.480933 \pm 0.052179$ \\
\hline
\end{tabular}

The spring group was sampled during April 2019; the summer group was sampled during June 2019; the autumn group was sampled during September 2019. Statistics for the spring group are based on 8 sampling transects except estuary (SL1); statistics for the summer and autumn groups are based on 7 sampling transects except two downstream transects (SL1 and SL2). 
Table 2

Seasonal variation of transport capacity, proportion of noneffective WBIF, half-life distance of the noneffective WBIF, and transportation effectiveness of watershed biological information flow (WBIF) from the upstream to downstream regions indicated by bacterial OTUs

\begin{tabular}{|c|c|c|c|c|c|c|c|}
\hline $\begin{array}{l}\text { Seasonal } \\
\text { group }\end{array}$ & $\begin{array}{l}\text { Weather } \\
\text { condition }\end{array}$ & $\begin{array}{l}\text { Transport } \\
\text { capacity } \\
\text { (per km) }\end{array}$ & $\begin{array}{l}\text { Proportion } \\
\text { of } \\
\text { noneffective } \\
\text { WBIF }\end{array}$ & $\begin{array}{l}\text { Half-life } \\
\text { distance of } \\
\text { the } \\
\text { noneffective } \\
\text { WBIF }\end{array}$ & $\begin{array}{l}\text { Transportation } \\
\text { effectiveness } \\
\text { (per km) }\end{array}$ & $\begin{array}{l}\text { Environmental } \\
\text { filtration from } \\
\text { rain point to } \\
\text { sunny point }\end{array}$ & $\begin{array}{l}\text { Environmental } \\
\text { filtration from } \\
\text { freshwater to } \\
\text { saline-water }\end{array}$ \\
\hline $\begin{array}{l}\text { Spring } \\
\text { group }\end{array}$ & $\begin{array}{l}\text { Frozen } \\
\text { days }\end{array}$ & $\begin{array}{l}0.999706 \\
\pm \\
0.000305\end{array}$ & $\begin{array}{l}0.668465 \pm \\
0.003435\end{array}$ & $\begin{array}{l}1.548987 \pm \\
0.126870\end{array}$ & $\begin{array}{l}0.758618 \pm \\
0.000304\end{array}$ & I & $\begin{array}{l}0.160427 \pm \\
0.008244\end{array}$ \\
\hline $\begin{array}{l}\text { Summer } \\
\text { group }\end{array}$ & $\begin{array}{l}\text { Rainy } \\
\text { days }\end{array}$ & $\begin{array}{l}0.994245 \\
\pm \\
0.000941\end{array}$ & $\begin{array}{l}0.434635 \pm \\
0.041681\end{array}$ & $\begin{array}{l}14.52338 \pm \\
1.440539\end{array}$ & $\begin{array}{l}0.974105 \pm \\
0.000926\end{array}$ & $\begin{array}{l}0.005687 \pm \\
0.005450\end{array}$ & $\begin{array}{l}0.544164 \pm \\
0.010042\end{array}$ \\
\hline $\begin{array}{l}\text { Autumn } \\
\text { group }\end{array}$ & $\begin{array}{l}\text { Cloudy } \\
\text { days }\end{array}$ & $\begin{array}{l}0.992250 \\
\pm \\
0.001452\end{array}$ & $\begin{array}{l}0.493504 \pm \\
0.041043\end{array}$ & $\begin{array}{l}10.398112 \pm \\
0.711122\end{array}$ & $\begin{array}{l}0.960671 \pm \\
0.001415\end{array}$ & / & $\begin{array}{l}0.128718 \pm \\
0.017062\end{array}$ \\
\hline
\end{tabular}

\section{WBIF of the Three Taxonomic Groups}

A total of 13,766, 7098, and 17,316 kinds of OTUs and 3532, 1032, and 6836 kinds of species were detected among the 18 summer samples, as indicated by the 16S rRNA gene, ITS gene, and C01 gene, respectively (Fig. 4 and Table S4). The types of OTUs and species detected in the water eDNA samples were generally higher than in the soil eDNA samples for all three taxonomic communities (Fig. 4). The common OTUs and species shared between the soil and water eDNA samples accounted for $71.98 \%$ and $87.95 \%, 60.40 \%$ and $76.18 \%$, and $37.93 \%$ and $53.52 \%$ of the total types of OTUs and species in the bacterial, fungal and eukaryotic group, respectively.

The transportation effectiveness of the bacterial, fungal, and eukaryotic WBIF from the riparian sampling site to the adjacent riverine sampling site was $62.76 \%, 44.79 \%$, and $22.64 \%$ at the OTU level, respectively, and $80.75 \%, 65.62 \%$, and $43.38 \%$ at the species level, respectively, among which both the transport capacity and environmental filtration significantly declined with the bacterial, fungal, and eukaryotic communities (Tables 3,S5,S6). The transportation effectiveness of bacterial, fungal and eukaryotic WBIF from upstream to downstream was $97.41 \%, 92.64 \%$, and $89.83 \%$ per $\mathrm{km}$ at the OTU level, and $98.69 \%, 95.71 \%$, and $92.41 \%$ per $\mathrm{km}$ at the species level, respectively, among which the noneffective WBIF decreased with the bacterial, fungal, and eukaryotic communities (Tables 4,S7,S8), and the half-life distance of the noneffective WBIF was 14.52, 4.93, and 4.07 km at the OTU level and 17.82, 5.96, and $5.02 \mathrm{~km}$ at the species level for the bacterial, fungal, and eukaryotic groups, respectively (Table 4). 
Table 3

Transport capacity, environmental filtration, and transportation effectiveness of watershed biological information flow (WBIF) from the riparian sampling site to the adjacent riverine water sampling site on summer rainy days, as indicated by three taxonomic groups

\begin{tabular}{|c|c|c|c|c|}
\hline Taxonomic group & $\begin{array}{l}\text { Taxonomic } \\
\text { level }\end{array}$ & $\begin{array}{l}\text { Transport } \\
\text { capacity }\end{array}$ & $\begin{array}{l}\text { Environmental } \\
\text { filtration }\end{array}$ & $\begin{array}{l}\text { Transportation } \\
\text { effectiveness }\end{array}$ \\
\hline \multirow[t]{2}{*}{$\begin{array}{l}\text { Bacteria (detected by the } 16 S \text { rRNA } \\
\text { gene) }\end{array}$} & OTU level & $\begin{array}{l}0.684876 \pm \\
0.091302\end{array}$ & $\begin{array}{l}0.083816 \pm \\
0.020574\end{array}$ & $0.627643 \pm 0.087327$ \\
\hline & species level & $\begin{array}{l}0.829912 \pm \\
0.066079\end{array}$ & $\begin{array}{l}0.027020 \pm \\
0.007048\end{array}$ & $0.807461 \pm 0.064521$ \\
\hline \multirow[t]{2}{*}{ Fungi (detected by the ITS gene) } & OTU level & $\begin{array}{l}0.600756 \pm \\
0.102865\end{array}$ & $\begin{array}{l}0.258922 \pm \\
0.054794\end{array}$ & $0.447896 \pm 0.095670$ \\
\hline & species level & $\begin{array}{l}0.738975 \pm \\
0.100006\end{array}$ & $\begin{array}{l}0.113469 \pm \\
0.016910\end{array}$ & $0.656191 \pm 0.097099$ \\
\hline \multirow[t]{2}{*}{$\begin{array}{l}\text { Metazoan (detected by the CO1 } \\
\text { gene) }\end{array}$} & OTU level & $\begin{array}{l}0.440871 \pm \\
0.124206\end{array}$ & $\begin{array}{l}0.485954 \pm \\
0.061102\end{array}$ & $0.226403 \pm 0.071669$ \\
\hline & species level & $\begin{array}{l}0.604263 \pm \\
0.092950\end{array}$ & $\begin{array}{l}0.281177 \pm \\
0.028991\end{array}$ & $0.433842 \pm 0.066684$ \\
\hline \multicolumn{5}{|c|}{$\begin{array}{l}\text { Bacteria (detected by the 16S rRNA gene), fungi (detected by the ITS gene), and metazoans (detected by the C01 gene) } \\
\text { indicate the groups of bacteria (detected by the } 16 \text { S rRNA gene), fungi (detected by the ITS gene), and metazoans (detected } \\
\text { by the C01 gene), respectively. Statistics in all groups are based on } 7 \text { sampling transects, except for two downstream } \\
\text { transects (SL1 and SL2). }\end{array}$} \\
\hline
\end{tabular}

Table 4

Transport capacity, proportion of noneffective WBIF, half-life distance of the noneffective WBIF, and transportation effectiveness of watershed biological information flow (WBIF) from the upstream to downstream regions on summer rainy days, indicated by three taxonomic groups at the OTU and species levels estimated by programming-solved according to the evolutionary algorithm

\begin{tabular}{|c|c|c|c|c|c|c|c|}
\hline $\begin{array}{l}\text { Taxonomic } \\
\text { group }\end{array}$ & $\begin{array}{l}\text { Taxonomic } \\
\text { level }\end{array}$ & $\begin{array}{l}\text { Transport } \\
\text { capacity } \\
\text { (per km) }\end{array}$ & $\begin{array}{l}\text { Proportion } \\
\text { of } \\
\text { noneffective } \\
\text { WBIF }\end{array}$ & $\begin{array}{l}\text { Half-life } \\
\text { distance of } \\
\text { the } \\
\text { noneffective } \\
\text { WBIF }\end{array}$ & $\begin{array}{l}\text { Transportation } \\
\text { effectiveness } \\
\text { (per km) }\end{array}$ & $\begin{array}{l}\text { Environmental } \\
\text { filtration from } \\
\text { rain point to } \\
\text { sunny point }\end{array}$ & $\begin{array}{l}\text { Environmental } \\
\text { filtration from } \\
\text { freshwater to } \\
\text { saline-water }\end{array}$ \\
\hline \multirow{2}{*}{$\begin{array}{l}\text { Bacteria } \\
\text { (detected } \\
\text { by the 16S } \\
\text { rRNA } \\
\text { gene) }\end{array}$} & OTU level & $\begin{array}{l}0.994245 \\
\pm \\
0.000941\end{array}$ & $\begin{array}{l}0.434635 \pm \\
0.041681\end{array}$ & $\begin{array}{l}14.52338 \pm \\
1.440539\end{array}$ & $\begin{array}{l}0.974105 \pm \\
0.000926\end{array}$ & $\begin{array}{l}0.005687 \pm \\
0.005450\end{array}$ & $\begin{array}{l}0.544164 \pm \\
0.010042\end{array}$ \\
\hline & $\begin{array}{l}\text { species } \\
\text { level }\end{array}$ & $\begin{array}{l}0.998188 \\
\pm \\
0.000121\end{array}$ & $\begin{array}{l}0.296484 \pm \\
0.010590\end{array}$ & $\begin{array}{l}17.82057 \pm \\
1.215028\end{array}$ & $\begin{array}{l}0.986898 \pm \\
0.000121\end{array}$ & $\begin{array}{l}0.051209 \pm \\
0.005337\end{array}$ & $\begin{array}{l}0.460245 \pm \\
0.001469\end{array}$ \\
\hline \multirow{2}{*}{$\begin{array}{l}\text { Fungi } \\
\text { (detected } \\
\text { by the ITS } \\
\text { gene) }\end{array}$} & OTU level & $\begin{array}{l}0.995550 \\
\pm \\
0.000680\end{array}$ & $\begin{array}{l}0.529290 \pm \\
0.016749\end{array}$ & $\begin{array}{l}4.925445 \pm \\
0.353730\end{array}$ & $\begin{array}{l}0.926377 \pm \\
0.000670\end{array}$ & $\begin{array}{l}0.003482 \pm \\
0.002886\end{array}$ & $\begin{array}{l}0.338354 \pm \\
0.003866\end{array}$ \\
\hline & $\begin{array}{l}\text { species } \\
\text { level }\end{array}$ & $\begin{array}{l}0.999484 \\
\pm \\
0.000244\end{array}$ & $\begin{array}{l}0.386710 \pm \\
0.008333\end{array}$ & $\begin{array}{l}5.961259 \pm \\
0.264864\end{array}$ & $\begin{array}{l}0.957057 \pm \\
0.000242\end{array}$ & $\begin{array}{l}0.000541 \pm \\
0.000258\end{array}$ & $\begin{array}{l}0.224685 \pm \\
0.001239\end{array}$ \\
\hline \multirow{2}{*}{$\begin{array}{l}\text { Metazoan } \\
\text { (detected } \\
\text { by the C01 } \\
\text { gene) }\end{array}$} & OTU level & $\begin{array}{l}0.989275 \\
\pm \\
0.000923\end{array}$ & $\begin{array}{l}0.587740 \pm \\
0.019079\end{array}$ & $\begin{array}{l}4.073058 \pm \\
0.362046\end{array}$ & $\begin{array}{l}0.898288 \pm \\
0.000908\end{array}$ & $\begin{array}{l}0.007897 \pm \\
0.006958\end{array}$ & $\begin{array}{l}0.716408 \pm \\
0.003182\end{array}$ \\
\hline & $\begin{array}{l}\text { species } \\
\text { level }\end{array}$ & $\begin{array}{l}0.992862 \\
\pm \\
0.000724\end{array}$ & $\begin{array}{l}0.537202 \pm \\
0.016816\end{array}$ & $\begin{array}{l}5.018684 \pm \\
0.317762\end{array}$ & $\begin{array}{l}0.924058 \pm \\
0.000713\end{array}$ & $\begin{array}{l}0.005337 \pm \\
0.002702\end{array}$ & $\begin{array}{l}0.607287 \pm \\
0.002642\end{array}$ \\
\hline $\begin{array}{l}\text { Bacteria (de } \\
\text { indicate the } \\
\text { by the C01 }\end{array}$ & $\begin{array}{l}\text { ed by the } \\
\text { ups of ba } \\
\text { e), respect }\end{array}$ & $\begin{array}{l}\text { RNA ger } \\
\text { (detecte }\end{array}$ & $\begin{array}{l}\text { ungi (detect } \\
\text { the } 16 \mathrm{~S} \mathrm{rR}\end{array}$ & $\begin{array}{l}\text { the ITS } \\
\text { ene), fun }\end{array}$ & ected by the I & $\begin{array}{l}\text { etected by th } \\
\text { ne), and met }\end{array}$ & $\begin{array}{l}1 \text { gene) } \\
\text { ans (detected }\end{array}$ \\
\hline
\end{tabular}




\section{Discussion}

Driven by the land-to-river and upstream-to-downstream WBIF, biodiversity information across terrestrial and aquatic biomes could be detected in riverine water eDNA ${ }^{6,16}$, and the monitoring effectiveness of riverine water eDNA relies on the transportation effectiveness of corresponding WBIF 6 ,17-20. The transportation effectiveness of WBIF mainly relies on the transport capacity, degradation rate, and environmental filtration of WBIF ${ }^{15,21-23}$, which can vary with different seasons and weather conditions ${ }^{26}$. We hypothesized that the monitoring effectiveness would vary with the seasons and weather conditions. In the present case, the bacterial community richness in soil did not vary with season, whereas the bacterial community composition in water was richest in the autumn, followed by the summer (Fig. 2,3). The transportation effectiveness of riparian-to-water and upstream-todownstream WBIF in spring frozen days was significantly lower than in summer rainy days and autumn cloudy days (Tables 1,2,S2,S3). It indicates that the monitoring effectiveness varied with different seasons and weather conditions, and summer and autumn were the optimal seasons, along with rainy days being the optimal weather condition, for using riverine water eDNA to simultaneously monitor the holistic biodiversity information in riverine sites and riparian sites.

The biodiversity information detected by water eDNA could originate from living and dead organisms ${ }^{23,26}$. The detection of biodiversity information that originates from a living organism mainly depends on the dispersal of this living organism ${ }^{11,20}$. The detection of biodiversity information that originates from a dead organism mainly depends on its transport capacity and degradation rate ${ }^{12,22,29}$. In summer and autumn, as driven by active organisms, more eDNA was input into the river system. In particular, the surface runoff caused by rain can input more eDNA from terrestrial soil into the river system and can preserve them in soil aggregates ${ }^{30}$. In the present study, the highest proportion of bacteria in riparian soil was detected in water in summer and autumn, and the rain promoted this phenomenon (Fig. 3 and Tables 1,S2). The proportion of effective upstream-todownstream WBIF was significantly higher in summer and autumn than in spring, as well as being higher on rainy days than on cloudy days (Table 2). eDNA (originated from dead organisms) degrades over time in a logistic manner (a half-life time) ${ }^{12,22,27,31}$, which was described in this study as degrading by half-life distance in a lotic system, which integrates the transport capacity and the degradation rate. In the present work, as driven by runoff discharge and flow velocity (Table S9), the half-life distance of noneffective WBIF was significantly farther in the summer than in autumn and in spring (Table 2).

The biodiversity information monitoring effectiveness of riverine water eDNA, as approximated by the transportation effectiveness of WBIF, was impacted by the eDNA degradation rate in WBIF, and there were taxonomy-specific eDNA degradation rates $^{27}$, species-specific eDNA degradation rates ${ }^{17}$, and form-specific eDNA degradation rates ${ }^{28}$. We hypothesized that the monitoring effectiveness of riverine water eDNA would vary with taxonomic communities. In the present case, the results revealed the detection of a significantly higher monitoring effectiveness of water eDNA (both riparian-to-water and downstreamto-upstream) for bacterial communities than for eukaryotic communities (Tables 3,4). A significantly higher monitoring effectiveness of water eDNA was found for micro eukaryotic communities (fungi) than for overall eukaryotic communities (including micro- and macro-organisms) (Tables 3,4). This indicates that the monitoring effectiveness varied with different taxonomic communities, and the effectiveness of monitoring eukaryotic communities was significantly lower than for monitoring bacterial communities; in addition, the effectiveness of monitoring macrobe communities was significantly lower than for monitoring microbe communities.

eDNA surveys that are based on metabarcoding can actually acquire information across the taxonomic tree of life $\mathrm{e}^{5,6,11,32,33}$. However, eDNA that originates from different taxonomic groups has a different probability of being left in the environment and input into water ${ }^{6,8,9,34}$. van Bochove et al. (2020) inferred that the eDNA contained inside of cells is especially resilient against degradation (i.e., intracellular vs. extracellular effects) ${ }^{28}$. In the present case, more bacteria than eukaryotes and more microorganisms than macroorganisms (both OTU and species levels) in riparian soil could be detected in water (Table 3). The half-life distance of noneffective WBIF for bacteria (detected by the 16s RNA gene) was much farther than that for unicellular eukaryotes (detected by the ITS gene, which is mainly unicellular), than that for multicellular eukaryotes (as detected by the CO1 gene, which is mainly multicellular) (Table 4). We inferred that the eDNA contained inside of bacterial cells was more resilient against degradation than that contained inside of unicellular eukaryotic cells (i.e., prokaryotic cells vs. eukaryotic cells), as well 
as compared to the eDNA contained inside of multicellular eukaryotic cells or extracellular mitochondria (i.e., unicellular eukaryotic cells vs. multicellular eukaryotic cells or extracellular).

In previous studies, the effectiveness of using water eDNA to monitor terrestrial organisms was indicated by the detection probability $8,9,34$, and the effectiveness of using downstream water eDNA to monitor upstream organisms was indicated by the detectable distance $7,12,17,19,20,35$. In this study, we approximated the biodiversity information monitoring effectiveness by the WBIF transportation effectiveness and proposed its assessment framework, in which we described the riparian-to-water monitoring effectiveness with the proportion of biodiversity information in riparian soil that was detected by using riverine water eDNA samples. Additionally, we described the downstream-to-upstream monitoring effectiveness with the proportion of biodiversity information in upstream site water eDNA samples that was detected by 1-km downstream site water eDNA samples, and the runoff distance of that $50 \%$ of dead bioinformation (i.e., the bioinformation labeling the biological material that lacked life activity and fertility) could be monitored. These indicators provided new usable assessment tools for designing monitoring projects and for evaluating monitoring results.

In the optimal monitoring season and weather condition (a summer rainy day) in the Shaliu river basin on the Qinghai-Tibet Plateau, by using riverine water eDNA, we were able to monitor as much as $87.95 \%$ of bacterial species, $76.18 \%$ of fungal species, and $53.52 \%$ of eukaryotic species from riparian soil (Table 3), along with as much as $98.69 \%$ of bacterial species, $95.71 \%$ of fungal species, and $92.41 \%$ of eukaryotic species from $1 \mathrm{~km}$ upstream (Table 4). The half-life distance of the noneffective WBIF was respectively $17.82 \mathrm{~km}, 5.96 \mathrm{~km}$, and $5.02 \mathrm{~km}$ for bacteria, fungi, and metazoans at the species level (Table 4). When considering the fact that the monitoring effectiveness of eDNA can not only vary with season, weather, and taxonomic communities, but can also vary with rivers and watersheds with different environmental conditions ${ }^{12,17,19,23}$, more studies on the monitoring effectiveness for each taxonomic community in other watersheds with different environmental conditions are needed.

eDNA metabarcoding surveys are relatively cheaper, more efficient, and more accurate than traditional surveys in aquatic systems $^{10,13}$, although this is certainly not true in all circumstances ${ }^{36}$. As the bioinformation in WBIF includes the biodiversity information of all taxonomic communities, the information of all taxonomic communities could be monitored by using riverine water eDNA, although variability in monitoring effectiveness exists among different taxonomic communities. We anticipate that, in future biodiversity research, conservation, and management, we will be able to efficiently monitor and assess the aquatic and terrestrial biodiversity by simply using riverine water eDNA samples.

In summary, to test the idea of using riverine water eDNA to simultaneously monitor aquatic and terrestrial biodiversity, we proposed a monitoring effectiveness assessment framework, in which the land-to-river monitoring effectiveness was indicated by detection probability, and the upstream-to-downstream monitoring effectiveness was described by the detection probability per kilometer runoff distance and by the half-life distance of dead bioinformation. In our case study, in the Shaliu River watershed on the Qinghai-Tibet Plateau, and on summer rainy days, $43-76 \%$ of species information in riparian sites could be detected in water eDNA samples, $92-99 \%$ of species information from upstream sites could be detected in a 1-km downstream eDNA sample, and the half-life distances of dead bioinformation for bacteria was approximately 13-19 km and was approximately 4-6 km for eukaryotes. The indicators in the assessment framework that describe the monitoring effectiveness provide usable assessment tools for designing monitoring projects and for evaluating monitoring results. In future ecological research, biodiversity conservation, and ecosystem management, riverine water eDNA may be a general diagnostic procedure for routine watershed biodiversity monitoring and assessment.

\section{Materials And Methods}

\section{Study Area}

The Shaliu River basin ( $\left.37^{\circ} 10^{\prime}-37^{\circ} 52^{\prime} \mathrm{N}, 100^{\circ} 17^{\prime}-99^{\circ} 32^{\prime} \mathrm{E}\right)$, as a sub-basin of the Qinghai Lake basin, is located $3196 \mathrm{~m}$ above sea level on the Qinghai-Tibet Plateau (Fig. 1). The Shaliu River is $106 \mathrm{~km}$ long, with a catchment area of $1320 \mathrm{~km}^{2}$. Grassland is the main land cover type, accounting for more than $90 \%$ of the watershed area. Less than $5 \%$ of the watershed area has been 
seriously changed by human activity, such as transformation into cultivated land and building land

(http://www.gangcha.gov.cn/html/2125/item.html). Due to its simple ecosystem assemblages and weak disturbance by human activity, the Shaliu River basin is a natural simplified model for investigating the effectiveness of monitoring aquatic and terrestrial biodiversity information using riverine water eDNA.

\section{Sampling and Sequencing}

To identify the seasonal variation of monitoring effectiveness, on April 8 and 9, June 25 and 26, and September 19 and 20 of 2019, we collected eDNA samples (spring group, summer group, and autumn group, respectively), including 27 soil eDNA samples and 27 water eDNA samples. The samples were collected from 9 transects (including riverine sampling sites and riparian sampling sites) of the Shaliu River (Fig. 1). The weather and hydrological conditions of each group are summarized in Table S9. A 5-mL surface soil sample was collected using a 5-mL sterilized centrifuge tube from the riparian site (5 $\mathrm{m}$ from the river) of each transect. A 1.5-L surface water sample was collected using a 1.5-L sterilized bottle (rinsed three times with sampling water) from the riverine site of each transect. Because keeping the samples cool can reduce the rate of eDNA decay and is a convenient and efficient method for conserving eDNA samples ${ }^{37}$, field samples were transported in an ice bath $\left(0^{\circ} \mathrm{C}\right)$ to the laboratory of the Rescue and Rehabilitation Center of Naked Carps of Qinghai Lake. To obtain the eDNA of most taxonomic communities ${ }^{25,38}$, water samples (with purified water used as a negative control) were filtered by using $0.2-\mu m$ membrane filters (JinTeng, Tianjin, PRC) to obtain the eDNA sample in the laboratory (with every step following the general rule of molecular ecology experimentation to control for contamination using bleach to wash the experimental apparatus). Subsequently, the filter membranes of each water sample were placed in a $50-\mathrm{mL}$ sterilized centrifuge tube. The samples were transported at $-20^{\circ} \mathrm{C}$ (in a dry ice bath), and stored at $-80^{\circ} \mathrm{C}$ (in an ultra-low temperature freezer) until DNA extraction. More details are provided in Table S10 and Supplementary Material 1.

To identify the taxonomic variation of monitoring effectiveness, we analyzed three taxonomic communities using the metabarcoding of the 16S rRNA, ITS, and mitochondrial C01 genes ${ }^{39-41}$. As long DNA fragments show a higher decay rate than short fragments ${ }^{22}$, short fragments better reflect community richness than long fragments ${ }^{22,31}$. We restricted the amplified fragment length to 300-500 bp and selected the primers 338F/806R, ITS1F/ ITS2R, and mICOlintF/ jgHCO2198R to detect bacteria, fungi, and metazoan, respectively ${ }^{39-41}$. As the extraction of eDNA ${ }^{42,43}$, amplification approach, and sequencing ${ }^{44}$ can impact the results of eDNA monitoring, a consistent DNA extraction method and amplification approach should be used for comparisons among samples ${ }^{41,45,46}$. Commercial eDNA labs can help ${ }^{11}$, in which all approaches (including eDNA extraction, primer synthesis, amplification approach, sequencing, and contamination control, among others) could be standard. In our work, samples were processed by Shanghai Majorbio Bio-pharm Technology Co., Ltd (Shanghai, China). The details are provided in Table S10 and Supplementary Material 1.

On the free online Majorbio Cloud Platform (www.majorbio.com), we analyzed the raw sequences data, and we obtained the types of operational taxonomic unit (OTU), the sequence number of each OTU, and the taxonomic features of each sample; additionally, we examined the community richness (Chao richness index at the OTU level).

\section{WBIF Analysis}

The WBIF (including land-to-river and upstream-to-downstream WBIF) of each group was assessed to reveal the effectiveness of using riverine water eDNA to monitor the biodiversity information in riverine sites and riparian sites. In the current WBIF analysis, all of the statistical analyses used the types of OTUs and species in each sample. The processing approach was simply described as follows (indicated by the OTU type).

The transportation effectiveness of WBIF was indicated by the proportion of input OTU types (i.e., the common types between the source site sample and the pool site sample) to output OTU types (the total types of source site sample) (Eq. 1).

$e=\frac{\operatorname{Num}\left(S_{\text {ОтU }} \cap P_{\text {OTU }}\right)}{\operatorname{Num}\left(S_{\text {ОтU }}\right)}($ Eq. 1$)$ 
where $e$ denotes the transportation effectiveness of WBIF; $S_{\text {OTU }}$ denotes the OTU assemblage of the source site sample (i.e., the adjacent soil eDNA sample in the land-to-river WBIF or the adjacent upstream water eDNA sample in the upstream-todownstream WBIF); and $P_{\text {OTU }}$ denotes the OTU assemblage of the pool site sample (i.e., the adjacent water eDNA sample in the land-to-river WBIF or the adjacent downstream water eDNA sample in the upstream-to-downstream WBIF).

As the distance of the land-to-river WBIF was less than $5 \mathrm{~m}$ in the present case study, the transportation effectiveness of the landto-river WBIF was assumed to be constructed by transport capacity and environmental filtration (no degradation rate). The transportation effectiveness of the land-to-river WBIF could be indicated by the proportion of the common types shared between adjacent soil eDNA samples and water eDNA samples to the total types of soil eDNA samples (Eq. 1). The transport capacity of the land-to-river WBIF could be indicated by the proportion of the common types shared between adjacent soil eDNA samples and water eDNA samples to the common types shared between the soil eDNA sample and all water eDNA samples in the corresponding group (Eq. 2). The environmental filtration of the land-to-river WBIF could be indicated by the proportion of the types included in the soil eDNA sample, but not in any water eDNA sample to the total types in the soil eDNA sample (Eq. 3).

$t=\frac{\operatorname{Num}\left(S_{\text {OTU }} \cap P_{\text {OTU }}\right)}{\operatorname{Num}\left(S_{\text {OTU }} \cap W_{\text {OTU }}\right)}($ Eq. 2)

$f=1-\frac{\operatorname{Num}\left(s_{\text {ОTU }} \cap W_{\text {OTU }}\right)}{\operatorname{Num}\left(s_{\text {ОтU }}\right)}($ Eq. 3)

where $t$ denotes the transport capacity; $f$ denotes the environmental filtration; $S_{\text {OTU }}$ denotes the OTU assemblage of the source site sample (i.e., the soil eDNA sample); and $W_{\text {OTU }}$ denotes the OTU assemblage of all water eDNA samples.

WBIF included the effective WBIF (i.e., the flow or migration of living organisms) and noneffective WBIF (i.e., the flow of the bioinformation labeling the biological material that lakced life activity and fertility [dead bioinformation]). The transportation effectiveness of upstream-to-downstream WBIF was determined by the different features of effective WBIF and noneffective WBIF. The effective WBIF was impacted by transport capacity and environmental filtration. The noneffective WBIF was impacted by transport capacity and degradation rate. We established the following presuppositions: (1) the transport capacity was consistent in a defined runoff condition of a definite season and weather condition; (2) the proportion of noneffective WBIF at each site was consistent; (3) the noneffective WBIF degraded over time (i.e., distance) in a logistic manner; and (4) the environmental filtration was consistent in a definite environmental change. These four presuppositions did not exactly describe the complex facts, but they provided a possibility of constructing a model to approximately address the complex facts. The transportation effectiveness of the upstream-to-downstream WBIF could be described by an equation (Eq. 4), in which the transportation effectiveness was the function of runoff distance, and the transport capacity, environmental filtration, and degradation rate were parameters that could be estimated according to the sets of transportation effectiveness and runoff distance. In practice, as WBIF are impacted by varying factors at any site and time, the analytical solution of the parameters in Eq. 4 is impossible. Therefore, we suggested that Eq. 4 could be programming-solved, according to the evolutionary algorithm in Microsoft Excel. As there were only approximate solutions of the parameters in Eq. 4, we suggested obtaining several sets (such as 30 sets) of approximate solutions, after which a statistical analysis could be performed for each parameter.

$e=t^{d} \times\left[(1-k) \times(1-f)+k \times\left(\frac{1}{2}\right)\left(\frac{d}{D}\right)\right]($ Eq. 4)

where $e$ denotes the transportation effectiveness of WBIF; $t$ denotes the transport capacity; $d$ denotes the distance of WBIF; $k$ denotes the proportion of the noneffective WBIF; $f$ denotes the environmental filtration; and $D$ denotes the half-life distance.

\section{Declarations}

Page 9/16 


\section{Acknowledgements}

This work was supported by the Central Public-Interest Scientific Institution Basal Research Fund, Chinese Academy of Fishery Sciences (grant numbers 2019HY-XKQ02, 2020TD08), the Natural Science Foundation of Qinghai (grant number 2018-ZJ-908), and the Department of Science and Technology of Qinghai Provence (grant number 2018-ZJ-703).

\section{Author Contributions}

H.Y., H.D., and H.Q. contributed to the conception of the study. H.Y. and L.Y. performed the field sampling. H.Y. and X.H. conducted the laboratory work. H.Y., H.Z., J.L., J.W., and C.W. contributed the acquisition, analysis, and interpretation of the data. Q.Z. administrated the project. H.Y. led the writing of the manuscript, and H.Z., J.L., J.W., C.W., and Q.W. contributed critically to the drafts and final version of the manuscript. Q.W. supervised and validated this study.

\section{Competing interests}

The authors declare that they have no known competing financial interests or personal relationships that could have appeared to influence the work reported in this paper.

\section{Data Accessibility}

The datasets that were generated for this study can be found in the China National GeneBank Sequence Archive (CNSA, https://db.cngb.org/cnsa/) of the China National GeneBank database (CNGBdb) under accession number CNP0001046.

\section{References}

1. Hooper, D. U. et al., A global synthesis reveals biodiversity loss as a major driver of ecosystem change. NATURE 486105 (2012).

2. Dixon, K. M., Cary, G. J., Worboys, G. L., Banks, S. C. \& Gibbons, P., Features associated with effective biodiversity monitoring and evaluation. BIOL CONSERV 238108221 (2019).

3. Anderson, C. B., Biodiversity monitoring, earth observations and the ecology of scale. ECOL LETT 211572 (2018).

4. Altermatt, F. et al., Uncovering the complete biodiversity structure in spatial networks: the example of riverine systems. OIKOS 129607 (2020).

5. Pawlowski, J., Apothéloz-Perret-Gentil, L. \& Altermatt, F., Environmental DNA: What's behind the term? Clarifying the terminology and recommendations for its future use in biomonitoring. MOL ECOL 294258 (2020).

6. Deiner, K., Fronhofer, E. A., Mächler, E., Walser, J. \& Altermatt, F., Environmental DNA reveals that rivers are conveyer belts of biodiversity information. NAT COMMUN7 12544 (2016).

7. Carraro, L., Hartikainen, H., Jokela, J., Bertuzzo, E. \& Rinaldo, A., Estimating species distribution and abundance in river networks using environmental DNA. P NATL ACAD SCI USA 11511724 (2018).

8. Seeber, P. A. et al., Terrestrial mammal surveillance using hybridization capture of environmental DNA from African waterholes. MOL ECOL RESOUR 191486 (2019).

9. Sales, N. G. et al., Fishing for mammals: Landscape-level monitoring of terrestrial and semi-aquatic communities using eDNA from riverine systems. J APPL ECOL 57707 (2020).

10. Lugg, W. H., Griffiths, J., van Rooyen, A. R., Weeks, A. R. \& Tingley, R., Optimal survey designs for environmental DNA sampling. METHODS ECOL EVOL 91049 (2018).

11. Ravindran, S., Turning discarded DNA into ecology gold. NATURE 570543 (2019).

12. Seymour, M., Rapid progression and future of environmental DNA research. Communications Biology 280 (2019).

Page 10/16 
13. Valentini, A. et al., Next-generation monitoring of aquatic biodiversity using environmental DNA metabarcoding. $M O L E C O L$ 25929 (2016).

14. Cristescu, M. E. \& Hebert, P. D. N., Uses and Misuses of Environmental DNA in Biodiversity Science and Conservation. Annual Review of Ecology, Evolution, and Systematics 49209 (2018).

15. Shogren, A. J. et al., Controls on eDNA movement in streams: Transport, Retention, and Resuspension. SCI REP-UK 75065 (2017).

16. Matsuoka, S. et al., Spatial structure of fungal DNA assemblages revealed with eDNA metabarcoding in a forest river network in western Japan. Metabarcoding and Metagenomics 3 e36335 (2019).

17. Deiner, K. \& Altermatt, F., Transport Distance of Invertebrate Environmental DNA in a Natural River. PLOS ONE 9 e88786 (2014).

18. Jerde, C. L. et al., Influence of Stream Bottom Substrate on Retention and Transport of Vertebrate Environmental DNA. ENVIRON SCI TECHNOL 508770 (2016).

19. Sansom, B. J. \& Sassoubre, L. M., Environmental DNA (eDNA) Shedding and Decay Rates to Model Freshwater Mussel eDNA Transport in a River. ENVIRON SCI TECHNOL 5114244 (2017).

20. Pont, D. et al., Environmental DNA reveals quantitative patterns of fish biodiversity in large rivers despite its downstream transportation. SCI REP-UK 810361 (2018).

21. Barnes, M. A. \& Turner, C. R., The ecology of environmental DNA and implications for conservation genetics. CONSERV GENET 171 (2016).

22. Jo, T. et al., Rapid degradation of longer DNA fragments enables the improved estimation of distribution and biomass using environmentaIDNA. MOL ECOL RESOUR 17 e25 (2017).

23. Tillotson, M. D. et al., Concentrations of environmental DNA (eDNA) reflect spawning salmon abundance at fine spatial and temporal scales. BIOL CONSERV 2201 (2018).

24. Fremier, A. K., Strickler, K. M., Parzych, J., Powers, S. \& Goldberg, C. S., Stream Transport and Retention of Environmental DNA Pulse Releases in Relation to Hydrogeomorphic Scaling Factors. ENVIRON SCI TECHNOL 536640 (2019).

25. Eichmiller, J. J., Best, S. E. \& Sorensen, P. W., Effects of Temperature and Trophic State on Degradation of Environmental DNA in Lake Water. ENVIRON SCI TECHNOL 501859 (2016).

26. Nukazawa, K., Hamasuna, Y. \& Suzuki, Y., Simulating the Advection and Degradation of the Environmental DNA of Common Carp along a River. ENVIRON SCI TECHNOL 5210562 (2018).

27. Barnes, M. A. et al., Environmental Conditions Influence eDNA Persistence in Aquatic Systems. ENVIRON SCI TECHNOL 48 1819 (2014).

28. Bochove, K. et al., Organic matter reduces the amount of detectable environmental DNA in freshwater. ECOL EVOL 103647 (2020).

29. Seymour, M. et al., Acidity promotes degradation of multi-species environmental DNA in lotic mesocosms. Communications Biology 14 (2018).

30. Wilpiszeski, R. L. et al., Soil Aggregate Microbial Communities: Towards Understanding Microbiome Interactions at Biologically Relevant Scales. APPL ENVIRON MICROB 85 e319 (2019).

31. Wei, N., Nakajima, F. \& Tobino, T., A microcosm study of surface sediment environmental DNA: decay observation, abundance estimation, and fragment length comparison. ENVIRON SCI TECHNOL 5212428 (2018).

32. Stat, M. et al., Ecosystem biomonitoring with eDNA: metabarcoding across the tree of life in a tropical marine environment. SCI REP-UK 712211 (2017).

33. Djurhuus, A. et al., Environmental DNA reveals seasonal shifts and potential interactions in a marine community. NAT COMMUN 11254 (2020).

34. Harper, L. R. et al., Environmental DNA (eDNA) metabarcoding of pond water as a tool to survey conservation and management priority mammals. BIOL CONSERV 238108225 (2019). 
35. Carraro, L., Mächler, E., Wüthrich, R. \& Altermatt, F., Environmental DNA allows upscaling spatial patterns of biodiversity in freshwater ecosystems. NAT COMMUN 113585 (2020).

36. Beng, K. C. \& Corlett, R. T., Applications of environmental DNA (eDNA) in ecology and conservation: opportunities, challenges and prospects. BIODIVERS CONSERV 292089 (2020).

37. Sales, N. G., Wangensteen, O. S., Carvalho, D. C. \& Mariani, S., Influence of preservation methods, sample medium and sampling time on eDNA recovery in a neotropical river. Environmental DNA 1119 (2019).

38. Li, J., Lawson Handley, L., Read, D. S. \& Hänfling, B., The effect of filtration method on the efficiency of environmental DNA capture and quantification via metabarcoding. MOL ECOL RESOUR 181102 (2018).

39. Wangensteen, O. S., Palacín, C., Guardiola, M. \& Turon, X., DNA metabarcoding of littoral hard-bottom communities: high diversity and database gaps revealed by two molecular markers. PEERJ 6 e4705 (2018).

40. Heeger, F., Wurzbacher, C., Bourne, E. C., Mazzoni, C. J. \& Monaghan, M. T., Combining the 5.8S and ITS2 to improve classification of fungi. METHODS ECOL EVOL 101702 (2019).

41. Giebner, H. et al., Comparing diversity levels in environmental samples: DNA sequence capture and metabarcoding approaches using 18S and COI genes. MOL ECOL RESOUR 201333 (2020).

42. Hermans, S. M., Buckley, H. L. \& Lear, G., Optimal extraction methods for the simultaneous analysis of DNA from diverse organisms and sample types. MOL ECOL RESOUR 18557 (2018).

43. Armbrecht, L. et al., An optimized method for the extraction of ancient eukaryote DNA from marine sediments. MOL ECOL RESOUR 20906 (2020).

44. Nichols, R. V. et al., Minimizing polymerase biases in metabarcoding. MOL ECOL RESOUR 18927 (2018).

45. Nicholson, A. et al., An analysis of metadata reporting in freshwater environmental DNA research calls for the development of best practice guidelines. Environmental DNA 2343 (2020).

46. Dopheide, A., Xie, D., Buckley, T. R., Drummond, A. J. \& Newcomb, R. D., Impacts of DNA extraction and PCR on DNA metabarcoding estimates of soil biodiversity. METHODS ECOL EVOL 10120 (2019).

\section{Figures}




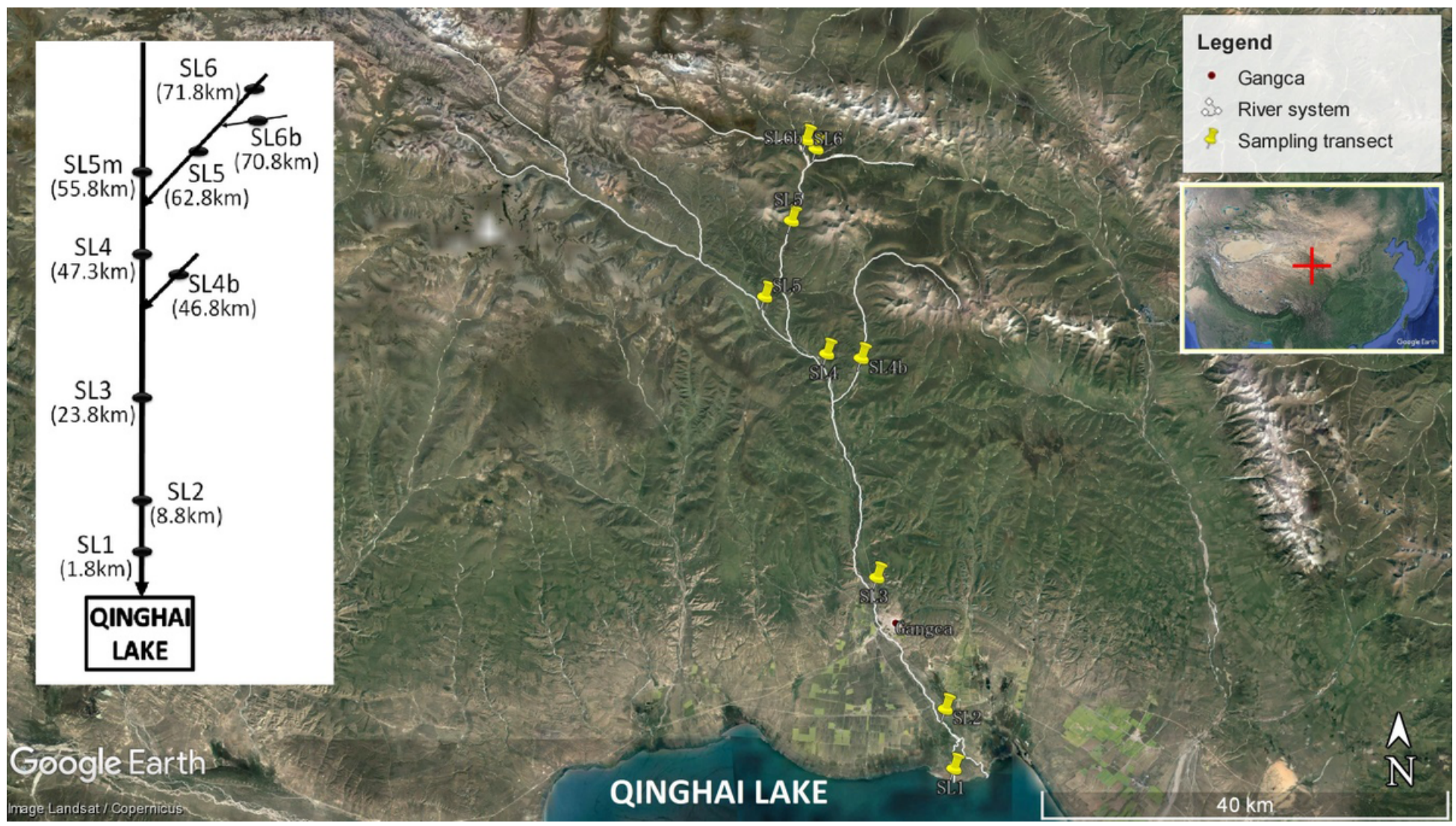

Figure 1

Sampling transects 

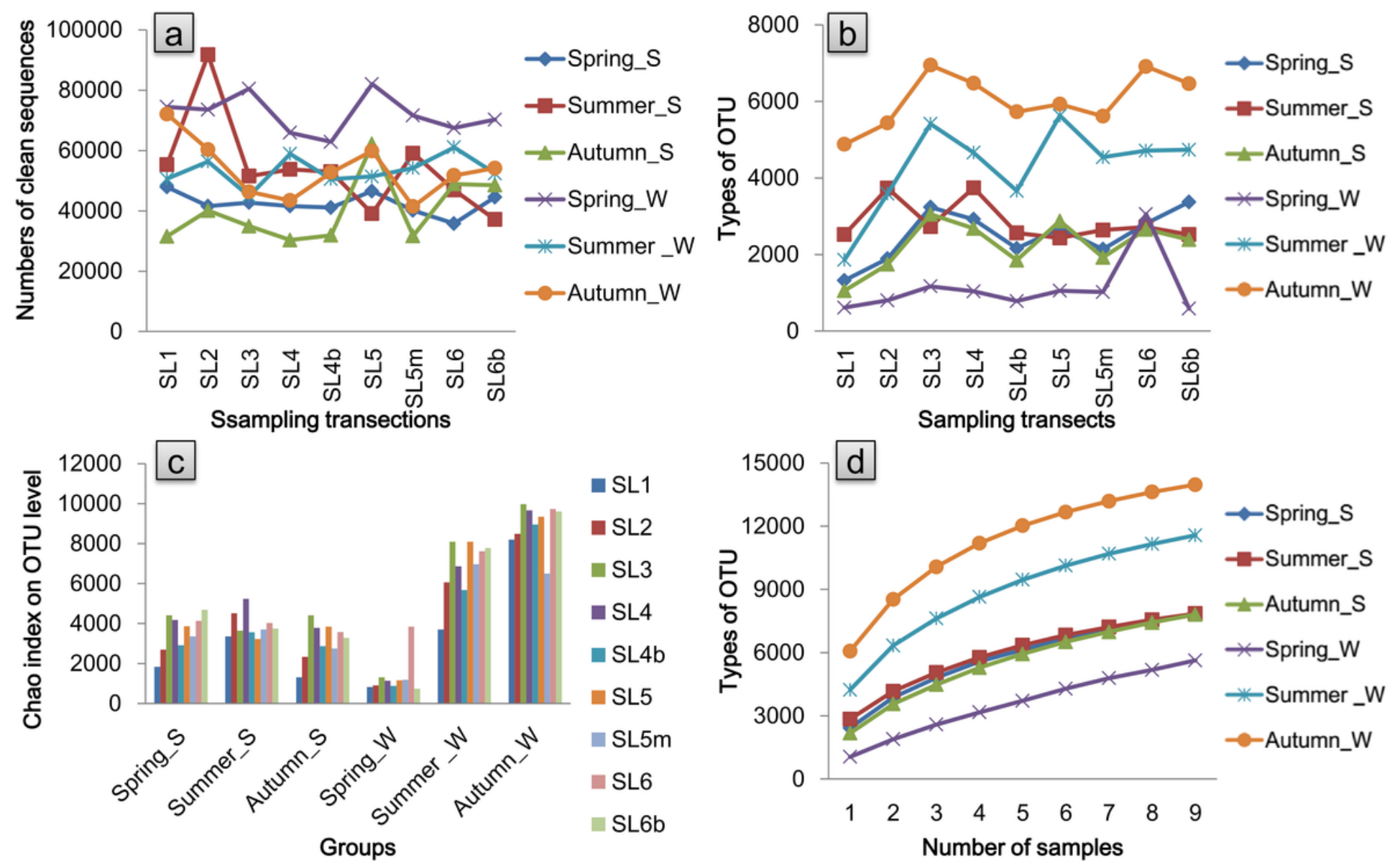

Figure 2

Biological information features of the samples: numbers of clean sequences in each sample (a), types of OTUs in each sample (b), community richness of each sample at the OTU level (c) and species accumulation curves at the OTU level (d) 


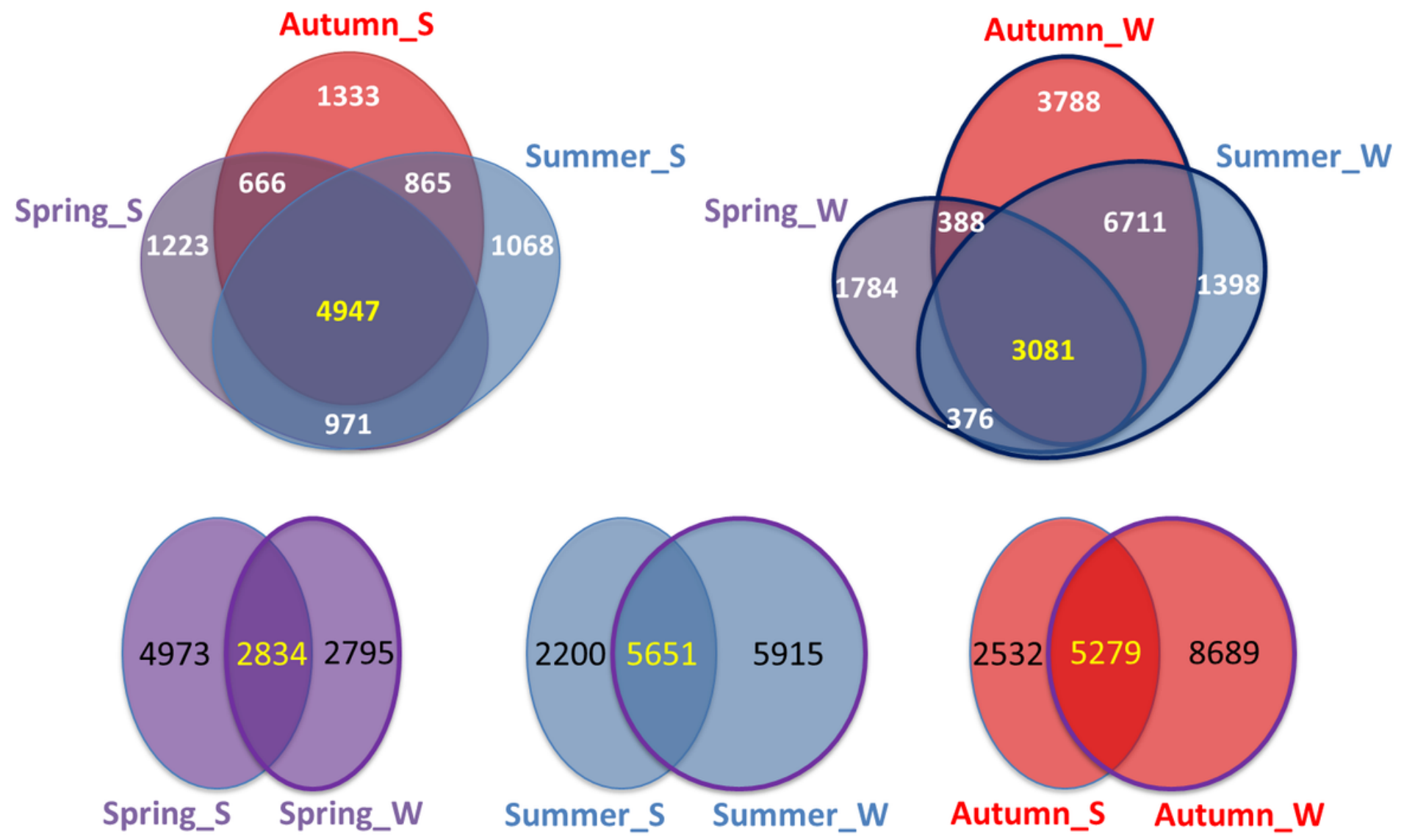

Figure 3

OTU types in riparian soil samples and riverine water samples shared by the three groups 

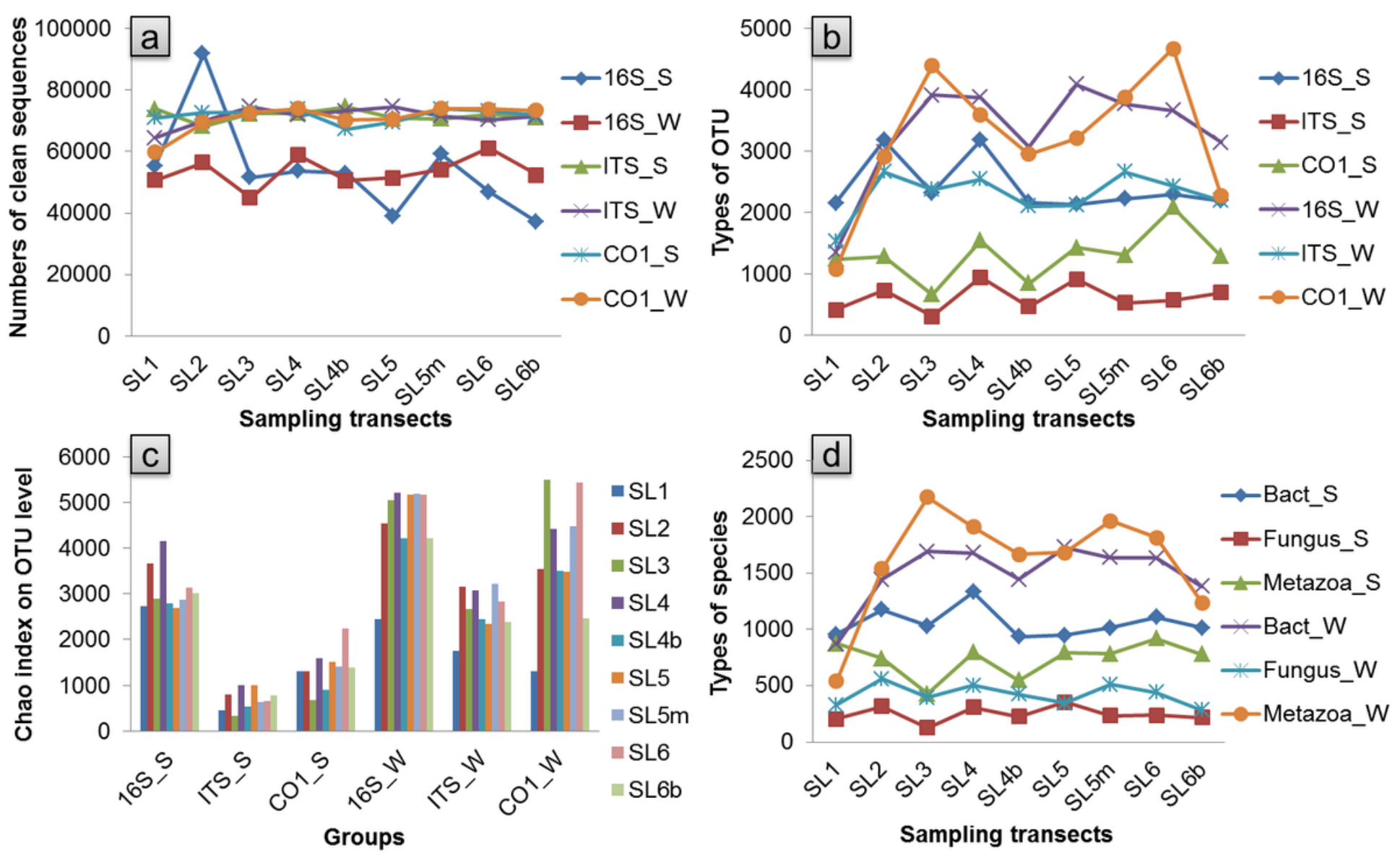

Figure 4

Biological information features of the samples: numbers of clean sequences in each sample (a), types of OTUs in each sample (b), community richness of each sample at the OTU level (c), and types of species in each sample (d)

\section{Supplementary Files}

This is a list of supplementary files associated with this preprint. Click to download.

- Supplementarymaterial1methods20210906e.docx

- Supplementarymaterial2tables20210906.docx 